\title{
INDUSTRIAL INFLUENCE ON THE INTERNATIONAL FREIGHT TRAFFIC OF THE LAND TRANSPORTS IN THE REPUBLIC OF BULGARIA
}

\section{Emil Jelezov}

“Todor Kableshkov" University of Transport, Sofia, Bulgaria

\section{Gergana Kirilova}

“Todor Kableshkov" University of Transport, Sofia, Bulgaria

OMESTE

JEL Category: L92, 018, R41

\begin{abstract}
The market demand and supply of transport services are in direct functional correlation with the industrial output and the consumption. The sectors "Mining and quarrying" and "Manufacturing" in the Republic of Bulgaria are generating the basic product flows thus determining the land transport market demand parameters in the country.

The paper is investigating and analyzing the current state and development tendencies of the industrial sector as well as the tendencies of basic indicators of the international exchange of the Republic of Bulgaria. The estimation results are systematically represented, the economic activities are determined and ranged according to their influence strength over the international land transport.
\end{abstract}

Keywords: Freight transport, industry, international transport.

\section{OBJECTIVES}

Purposes of the analysis:

- determining the modal shares of road and rail transport in international trade;

- determining the trends of the industrial development in the Republic of Bulgaria;

- determining the development trends of international land transport;

Address of the corresponding author:

Emil Jelezov

拝=゙ ejelezov@abv.bg
- identification of the freight structure represented by different goods in the international road and rail transport;

- identification of main directions and key partners in the international stock exchange based upon land transport;

- determining the influence rate of the industry over the international freight.

\section{METHODOLOGY}

The objects of the survey are international railway and road transport, industry and international trade of Bulgaria. Using Eurostat statistical data (EC, 2016), the trade turnover of Bulgaria is 
analyzed in physical units (tons) based upon the following sections and combinations (Jelezov \& Kirilova, 2015):

- export and import divided by partner countries;

- export and import by groups of cargo per SITC ${ }^{1}$;

- differentiated freight structure by commodities;

- export and import divided by modes of transport (only for non-EU member countries) per classification $S N T / R^{2}$ in physical units (tons).

The international trade is studied based upon physical units per classification SITC.

The reference period of the analysis is 2007 2013.
The trends of industrial development are studied based upon National Statistical Institute (NSI, 2016) data about the indices of production and per economic activities.

\section{$3 \quad$ RESULTS AND DISCUSSIONS}

\subsection{Modal split in the international trade}

The modal split data about import and export by modes of transport are represented by figures 1 , 2, 3 and 4.

\section{EU27_EXTRA-Import ( $\mathrm{t})$}

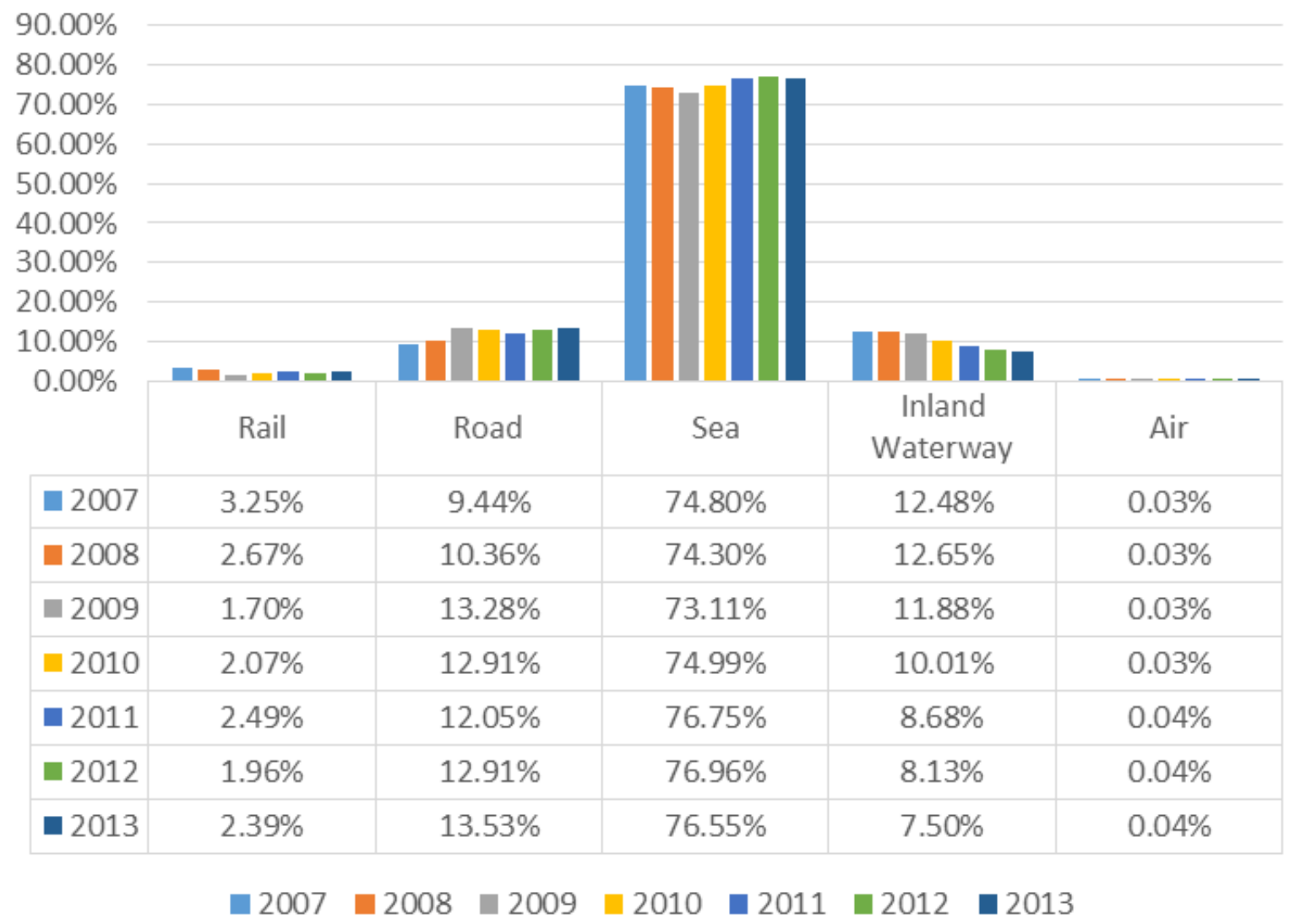

Fig. 1 Modal split in the import
${ }_{1}$ Standard International Trade Classification. $\quad 2$ Standard Goods Classification for Transport Statistics/Revised (NST/R).




\section{EU27_EXTRA- export (t)}

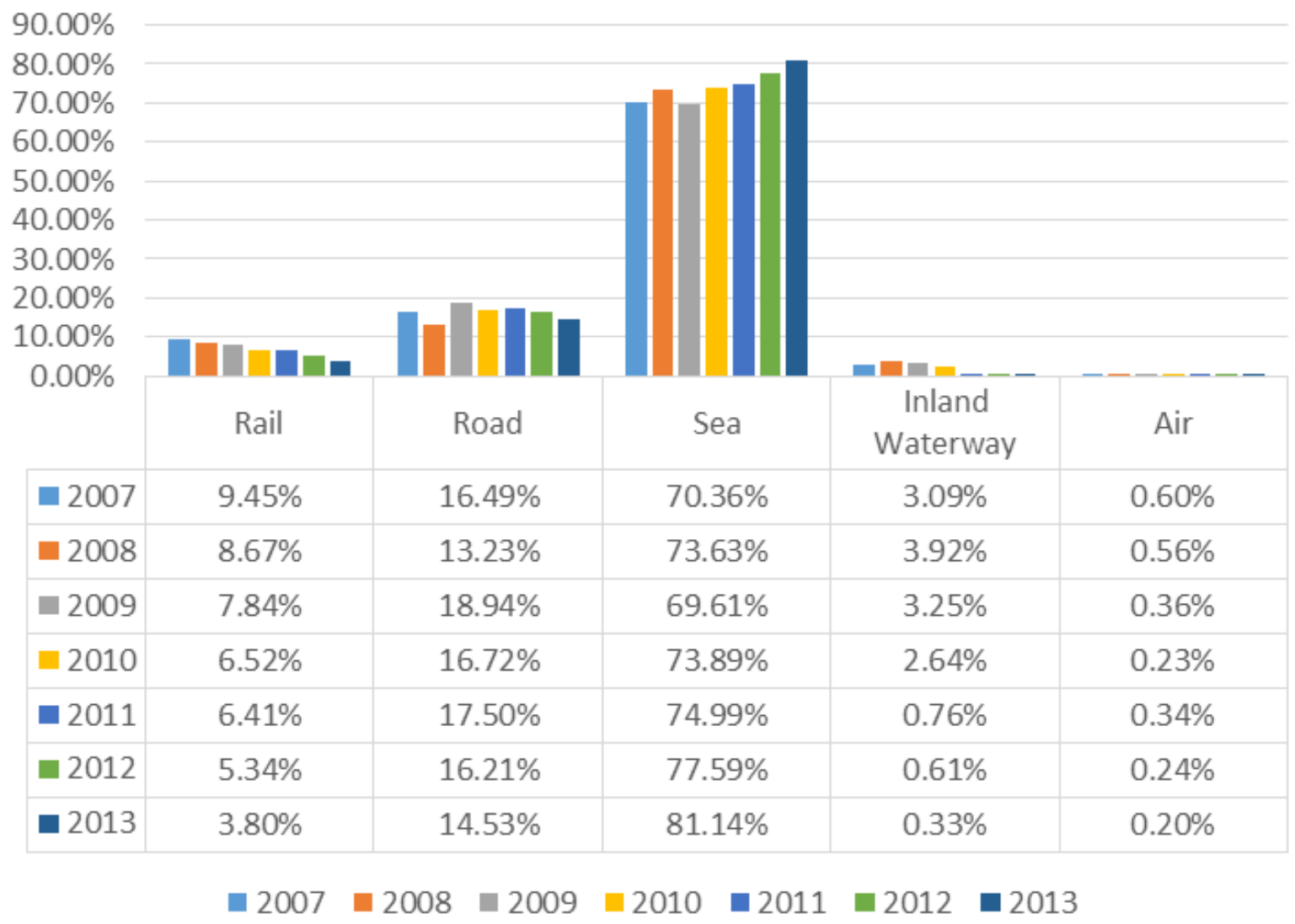

Fig. 2 Modal split in the export

\section{Modal split of imports by type of land transport}

$120.00 \%$

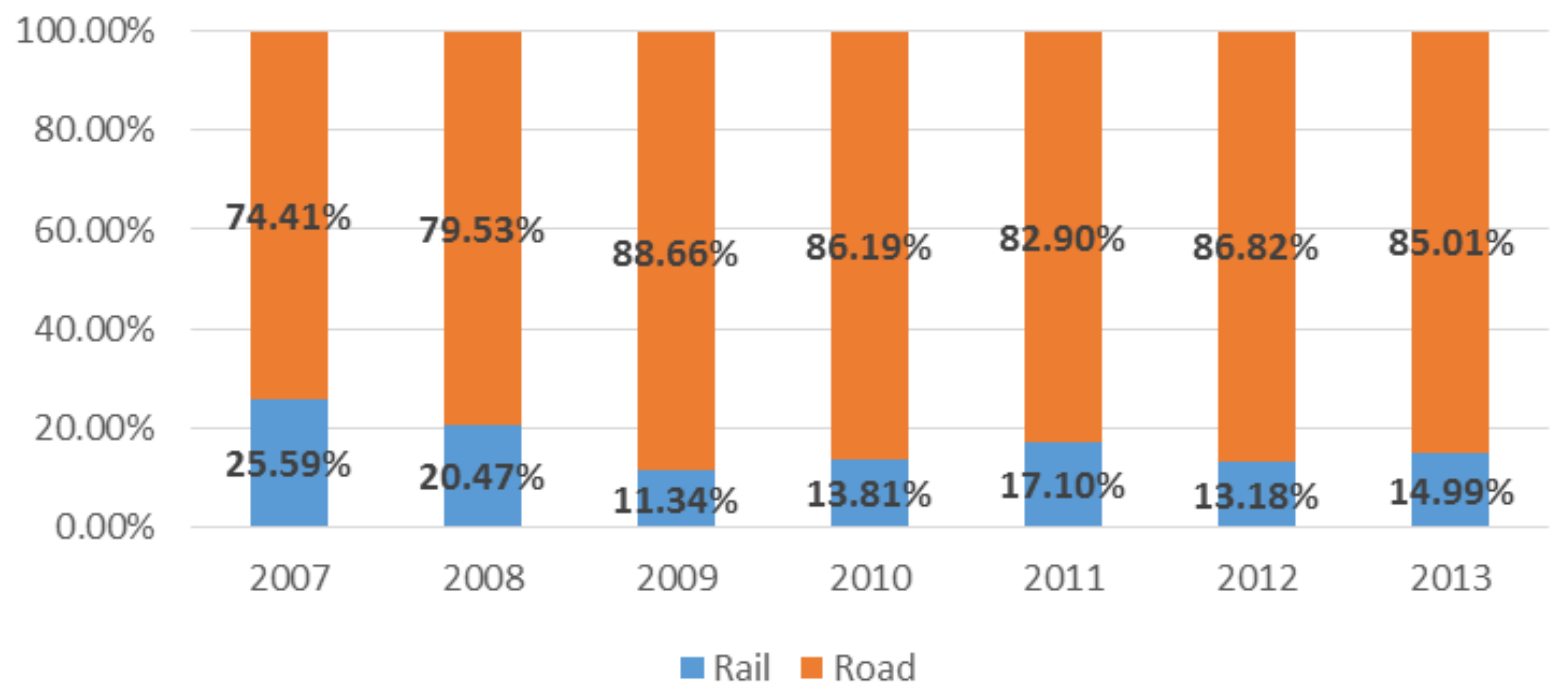

Fig. 3 Modal split of imports by type of land transport 


\section{Modal split of exports by type of land transport}

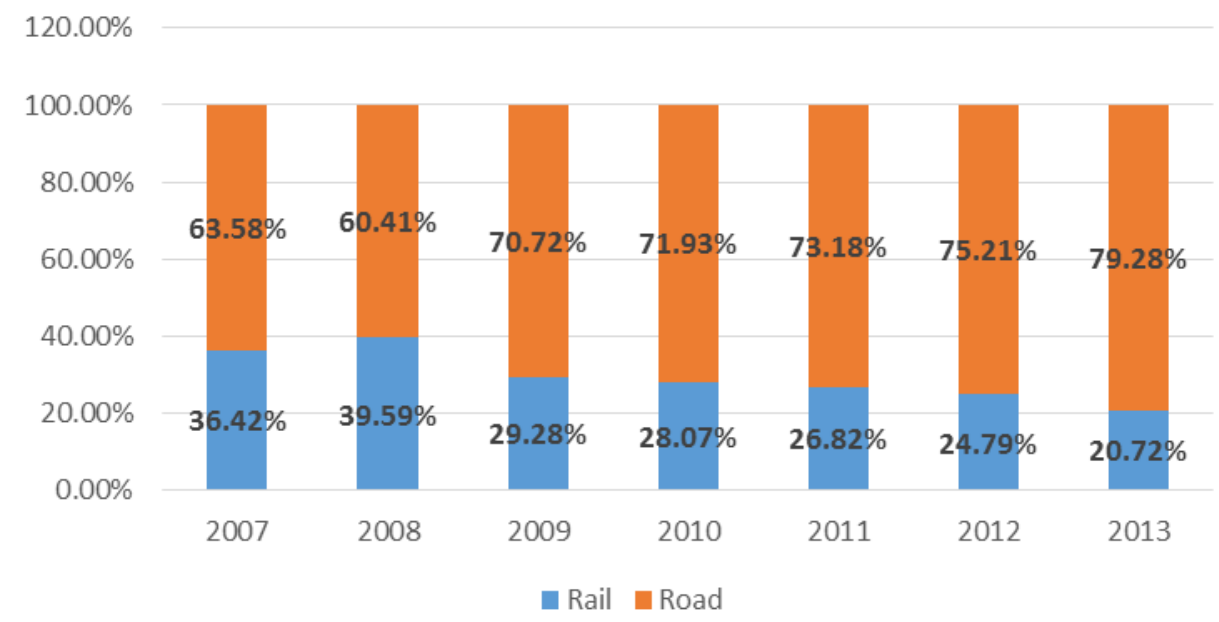

Fig. 4 Modal split of export by type of land transport

\section{Conclusions:}

- Basic share in international trade with tendency towards increasing belongs to maritime transport both in import (75\%-77\%) as well as export (70\%-81\%);

- The overall share of land transport during the study period has increased from $12.69 \%$ to $15.92 \%$;

- The share of railway transport in import during the study period has decreased from $3.25 \%$ to $2.39 \%$;

- The share of railway transport in export during the study period has decreased from $9.45 \%$ to $3.80 \%$;

- The share of road transport in import has increased from $9.44 \%$ to $13.53 \%$;

- The share of road transport in export has decreased from $16.49 \%$ to $14.53 \%$;

- The share of road transport in international freight with land transport has increased from $74.41 \%$ to $85.01 \%$ in import and from $63.58 \%$ to $79.28 \%$ in export.

\subsection{Main commodities per transport modes}

Table 5 indicates the shares of different commodity groups by directions and modes of transport.

\section{Conclusions:}

- For import by road transport leading are the following commodity groups:
- machinery, transport equipment, manufactured articles and miscellaneous articles;

- agricultural products and live animals;

- chemicals;

- metal products;

- foodstuffs and animal fodder.

These groups account for over $80 \%$ of the import with road transport.

- For export by road transport leading are the following commodity groups:

- crude and manufactured minerals, building materials;

- machinery, transport equipment, manufactured articles and miscellaneous articles;

- chemicals;

- ores and metal waste;

- agricultural products and live animals.

These groups account for over $79 \%$ of the export with road transport.

- For import by railway transport leading are the following commodity groups:

- petroleum products;

- ores and metal waste;

- metal products;

- crude and manufactured minerals, building materials;

- machinery, transport equipment, manufactured articles and miscellaneous articles. 
Jelezov E. Industrial influence on the freight traffic MEST Journal Vol. 5 No. 1 pp. 47-56

These groups account for over $91 \%$ of the import with railway transport.

- For export by railway transport leading are the following commodity groups:

- foodstuffs and animal fodder;

- ores and metal waste;
- chemicals;

- petroleum products;

- fertilizers;

- agricultural products and live animals.

These groups account for over $77 \%$ of the export with railway transport.

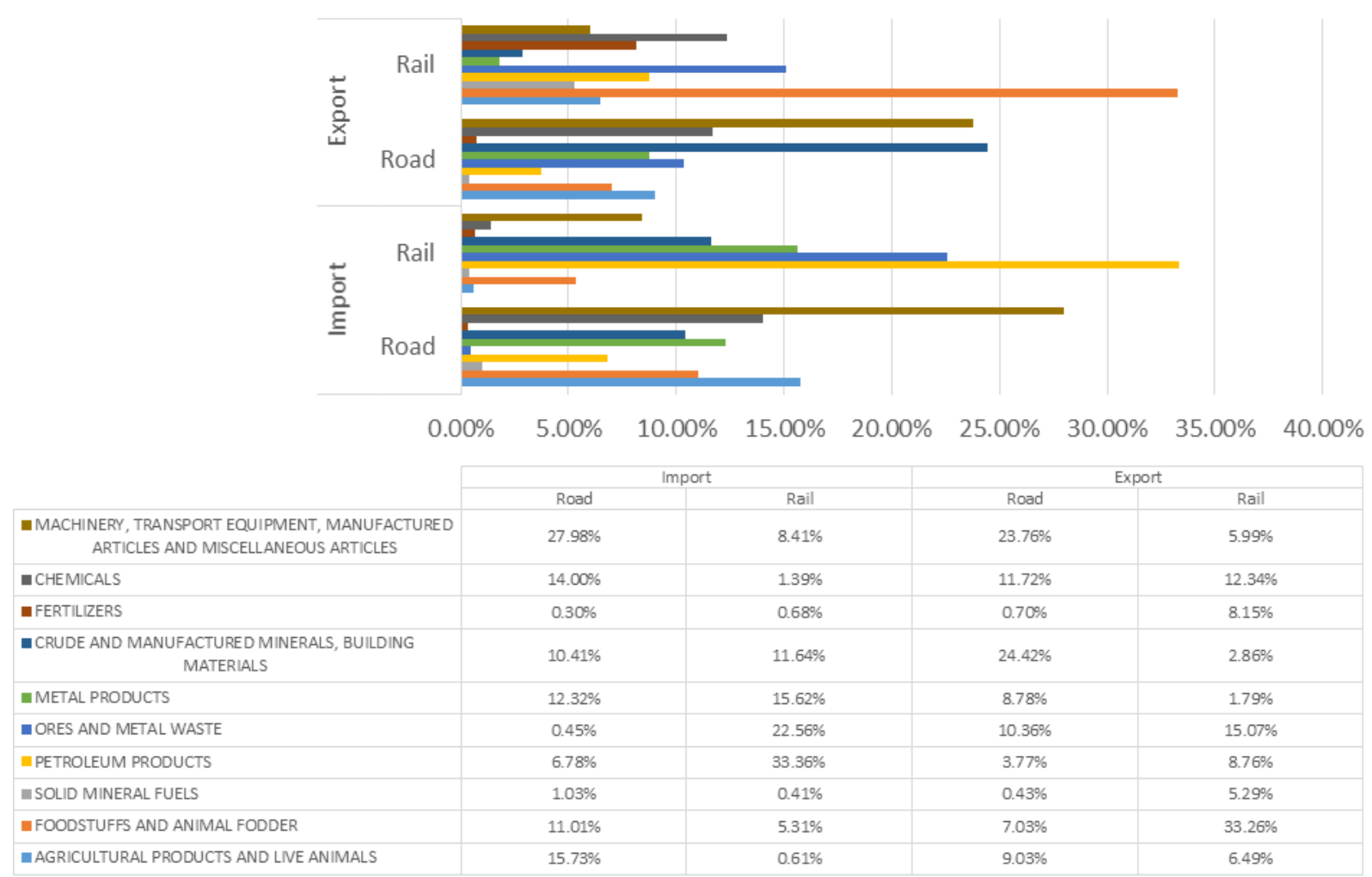

Fig. 5 Main commodities by transport modes

\section{Import by road}

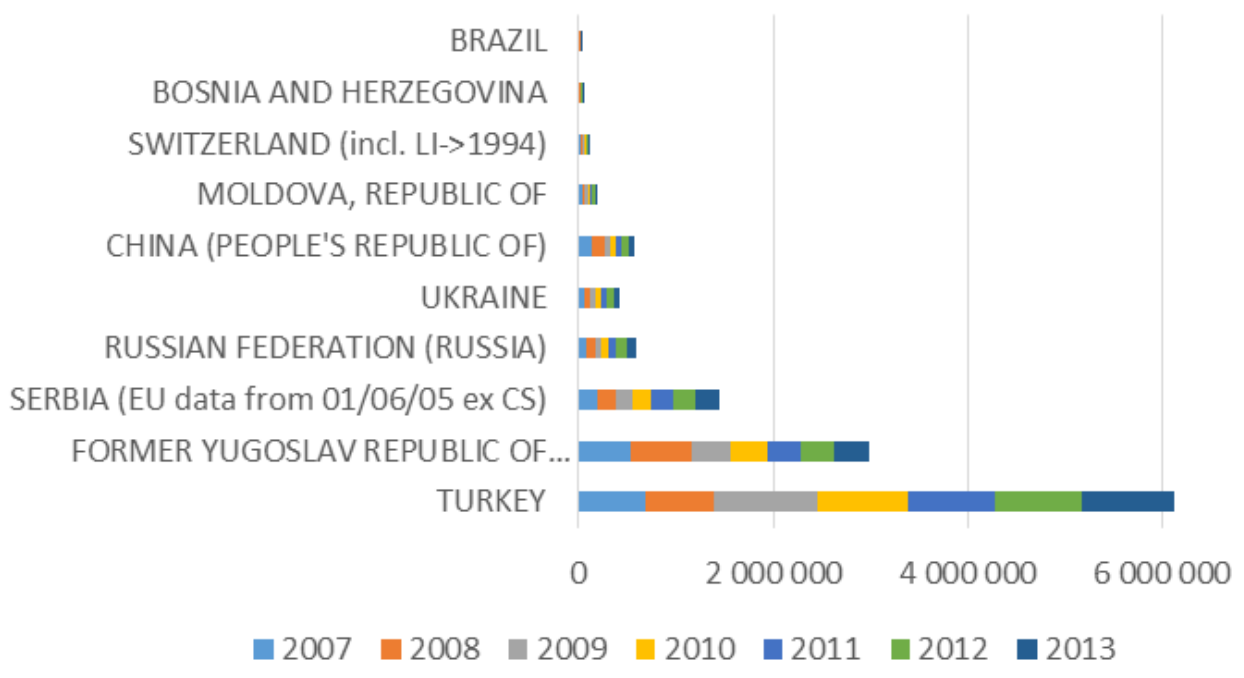

Fig. 6 Key country-partners (road, import) 


\subsection{Key country-partners per transport mode}

Figures 6, 7, 8 and 9 represent data about the road and rail transport freight haulage by commodities and directions (import and export).

Conclusions:

- The basic partner countries for road transport haulage are Turkey, Former Yugoslav Republic of Macedonia, Serbia, Russian federation. These countries account for over
$84 \%$ of the import and over $79 \%$ of the export by road transport;

- The basic partner countries for rail transport freight in import are Serbia, Kazakhstan, Russian federation $и$ Ukraine. These countries together account for accumulation of over $77 \%$ of the import by rail transport;

- The basic partner countries for rail transport freight in export are Turkey, Former Yugoslav

Republic of Macedonia, Serbia, Russian federation. These countries account for over $87 \%$ of the export by railway transport

\section{Export by road}

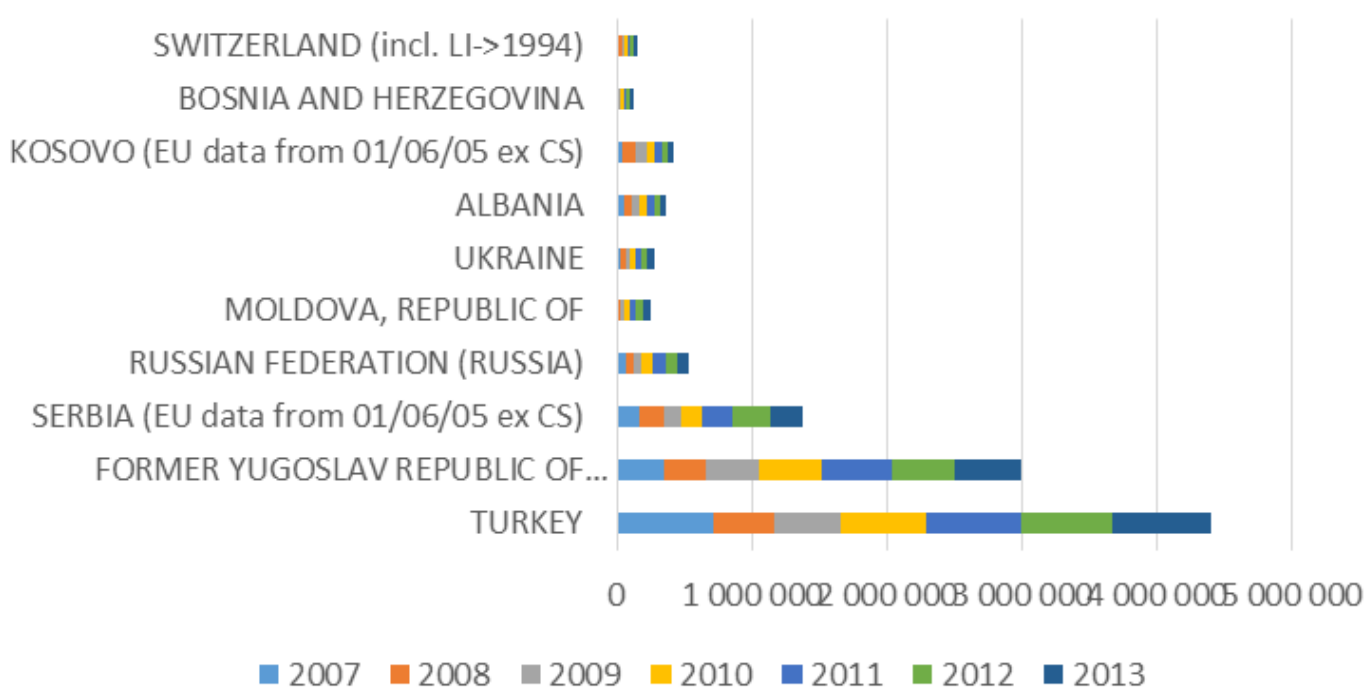

Fig. 7 Key country-partners (road,export)

\section{Import by rail}

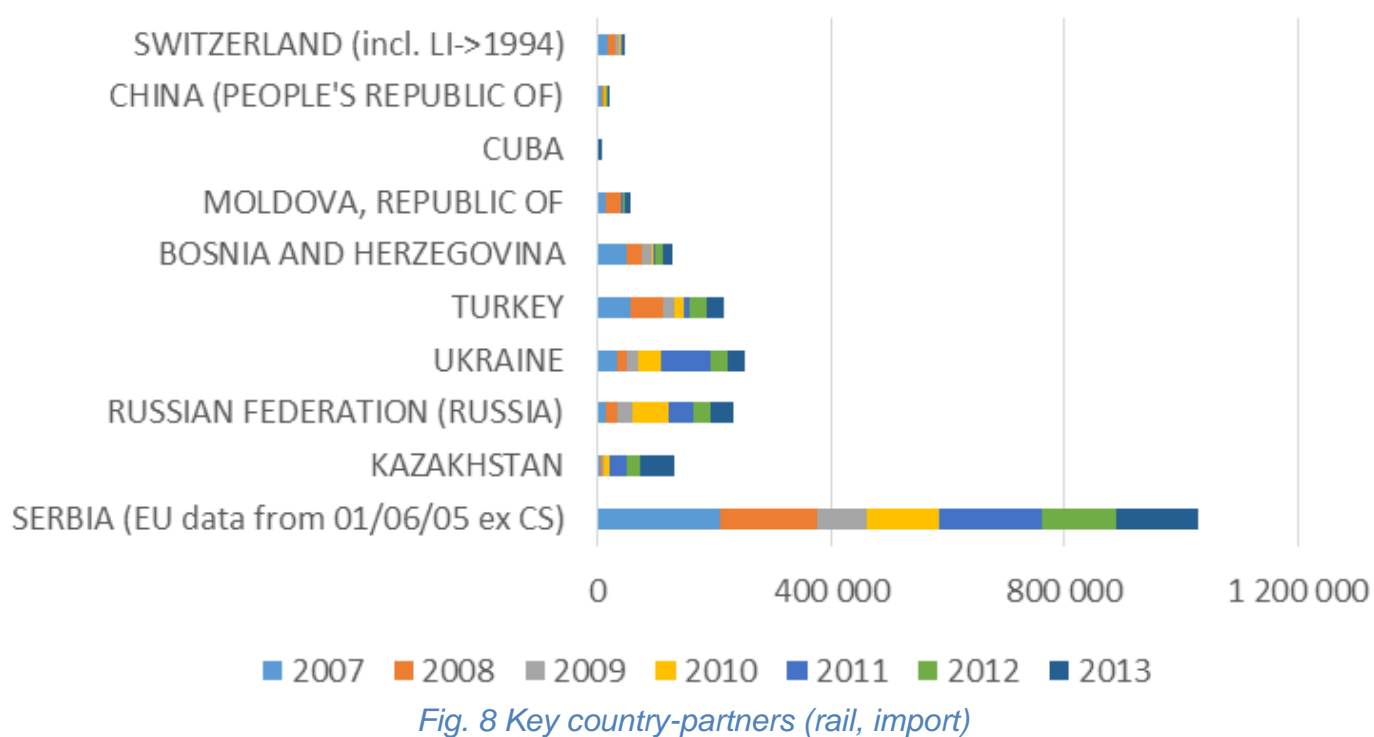




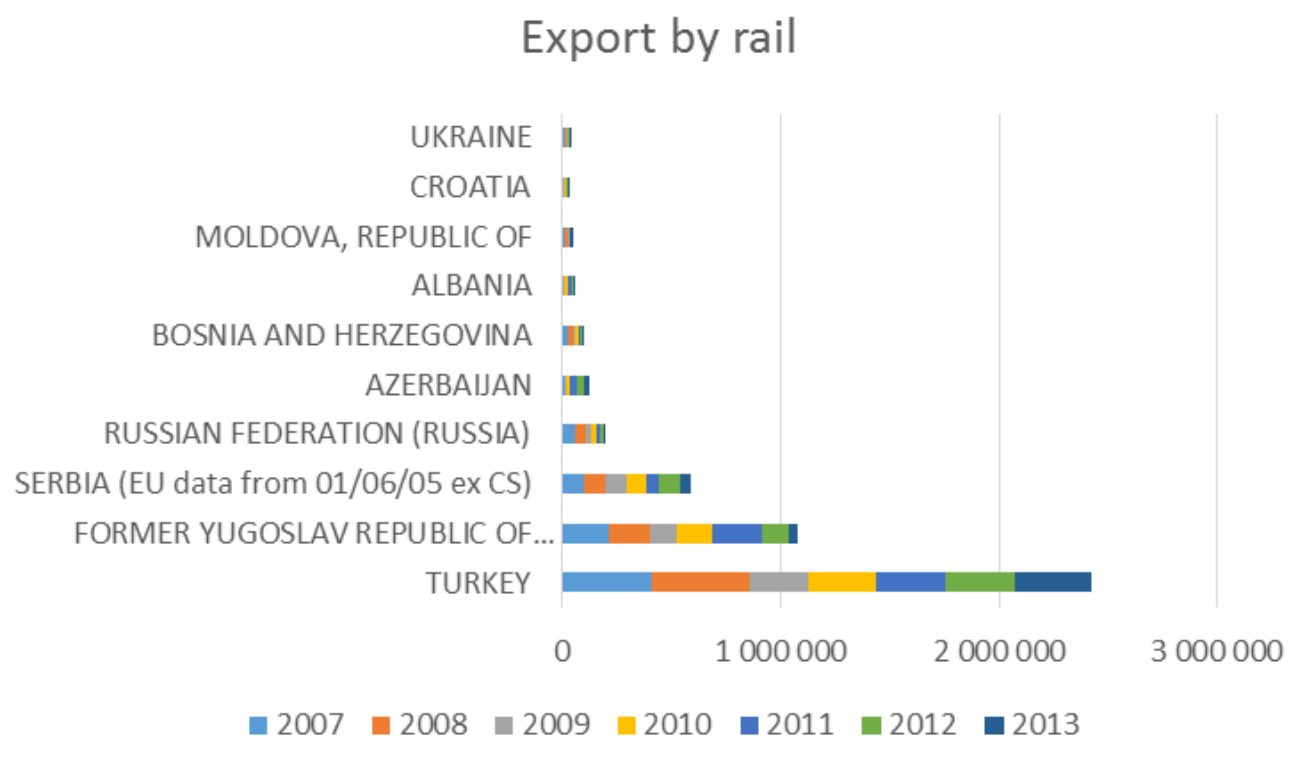

Fig. 9 Key country-partners (rail, export)

\subsection{Impact of the industry on the international land transport}

The industrial influence over the international freight carriages is estimated through determining correlation rates between the freight carriage alteration indices and the industrial output alterations indices.

The freight carriage alteration indices are indicated on figure 10 (for export) and figure 11 (import).

Export indices, $2007=100$

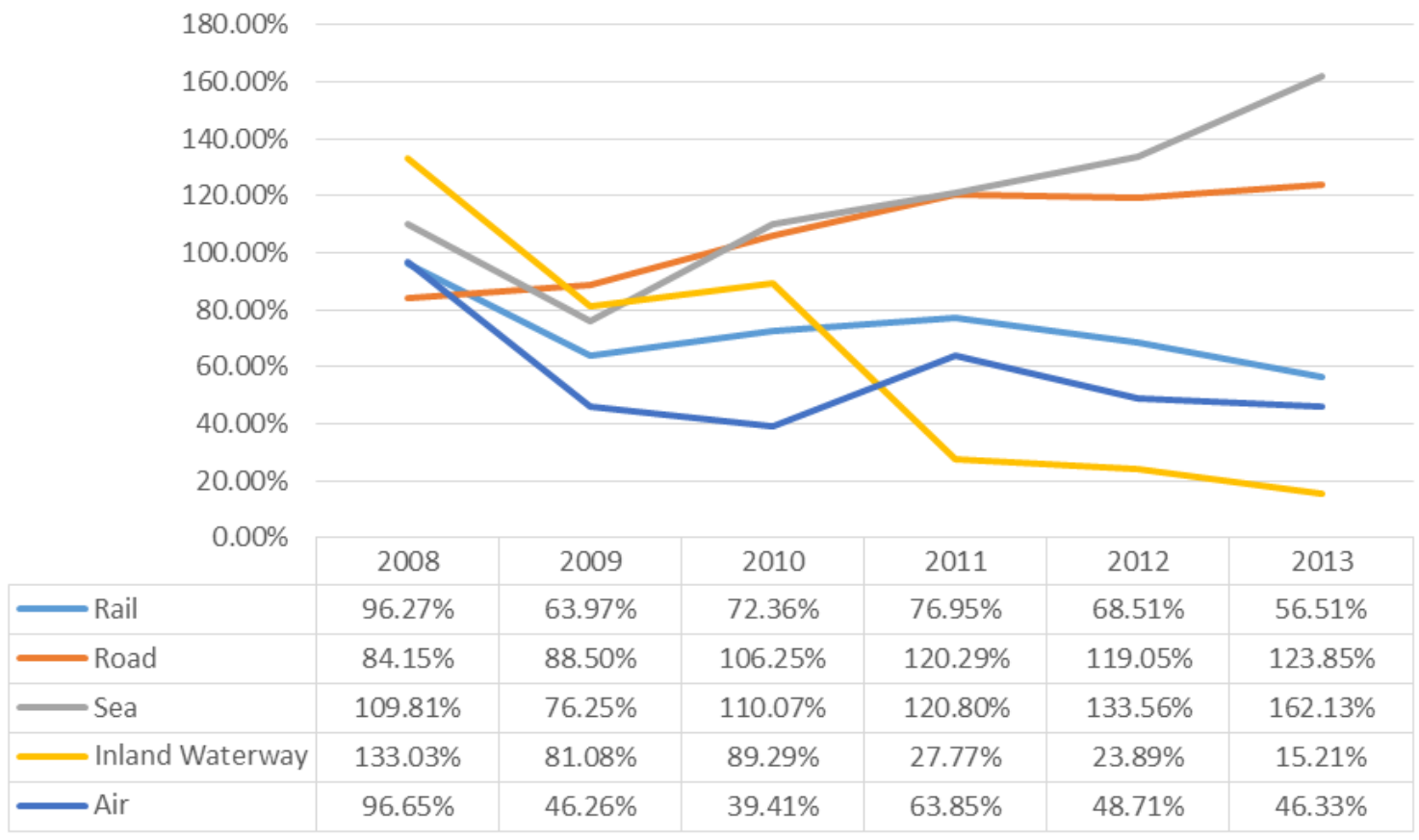

Fig. 10 Export indices, 2007=100\% 
1.2

1

0.8

0.6

0.4

0.2

\begin{tabular}{|c|c|c|c|c|c|c|}
\hline 0 & 2008 & 2009 & 2010 & 2011 & 2012 & 2013 \\
\hline Rail & & $79.68 \%$ & $38.57 \%$ & $45.59 \%$ & $56.76 \%$ & $43.05 \%$ \\
\hline Road & & $106.50 \%$ & $103.71 \%$ & $97.87 \%$ & $94.68 \%$ & $97.59 \%$ \\
\hline$\longrightarrow$ Sea & & $96.39 \%$ & $72.02 \%$ & $71.76 \%$ & $76.08 \%$ & $73.40 \%$ \\
\hline _ Inland Waterway & & $98.32 \%$ & $70.14 \%$ & $57.41 \%$ & $51.53 \%$ & $46.48 \%$ \\
\hline - Air & & $116.09 \%$ & $69.55 \%$ & $70.79 \%$ & $96.91 \%$ & $107.43 \%$ \\
\hline
\end{tabular}

Fig. 11 Import indices, 2007=100

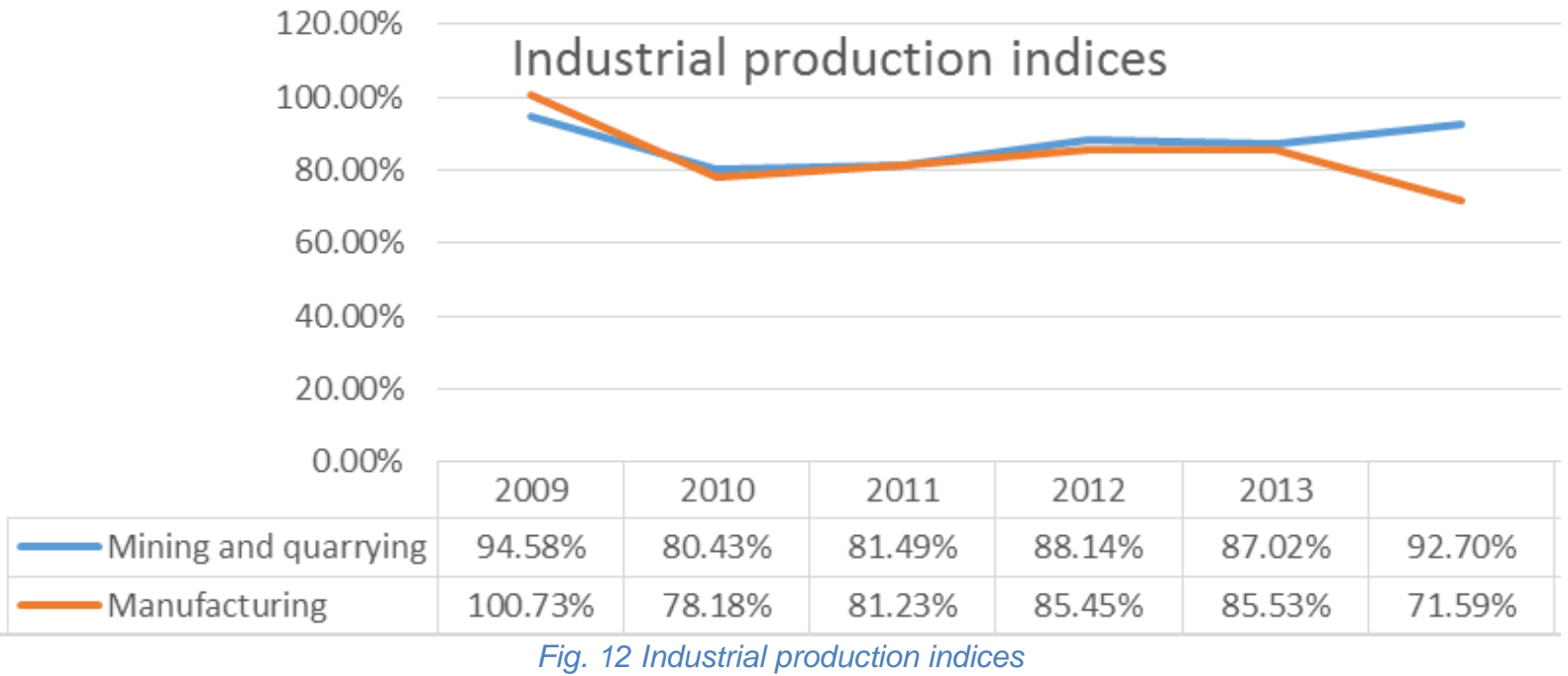

The estimation of the strength of industrial influence over freight carriages the following scale is applied:

\begin{tabular}{|l|}
\hline Correlation strength \\
\hline $0.3<\mathrm{R}<0.5-$ moderate \\
\hline $0.5<\mathrm{R}<0.7-$ considerable \\
\hline $0.7<\mathrm{R}<0.9-$ high \\
\hline $0.9<\mathrm{R}<1,0$ - very high \\
\hline
\end{tabular}

The estimation results are systematically represented; the economic activities are determined and ranked according to their influence strength over the international land transport. The results are represented in tables 1 to 5 . 
Table 1. Impact assessment for rail-very high

\begin{tabular}{|c|c|c|}
\hline \multicolumn{3}{|c|}{$\begin{array}{l}\text { Correlation coefficients } \\
0.9<R<1,0 \text {-very high }\end{array}$} \\
\hline $\begin{array}{l}\text { Rail- } \\
\text { import }\end{array}$ & $\begin{array}{l}\text { Manufacture of other non- } \\
\text { metallic mineral products }\end{array}$ & 0.90 \\
\hline \multirow{5}{*}{ 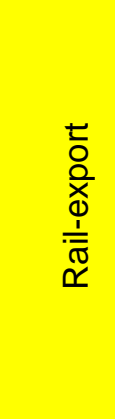 } & $\begin{array}{l}\text { Manufacture of fabricated } \\
\text { metal products, except } \\
\text { machinery and equipment }\end{array}$ & 0.98 \\
\hline & Manufacture of furniture & 0.96 \\
\hline & $\begin{array}{l}\text { Repair and installation of } \\
\text { machinery and equipment }\end{array}$ & 0.92 \\
\hline & Intermediate goods & 0.98 \\
\hline & Investment goods & 0.93 \\
\hline
\end{tabular}

Table 2. Impact assessment for rail-high

\begin{tabular}{|c|c|c|}
\hline \multicolumn{3}{|c|}{$\begin{array}{c}\text { Correlation coefficients } \\
0.7<R<0.9-\text { high } \\
\end{array}$} \\
\hline \multirow{10}{*}{ 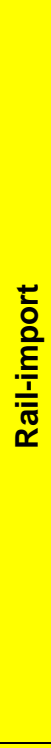 } & Manufacture of beverages & 0.77 \\
\hline & $\begin{array}{l}\text { Manufacture of wood and of } \\
\text { products of wood and cork, except } \\
\text { furniture; manufacture of articles of } \\
\text { straw and plaiting materials }\end{array}$ & 0.74 \\
\hline & $\begin{array}{l}\text { Manufacture of chemicals and } \\
\text { chemical products }\end{array}$ & 0.83 \\
\hline & $\begin{array}{l}\text { Manufacture of fabricated metal } \\
\text { products, except machinery and } \\
\text { equipment }\end{array}$ & 0.72 \\
\hline & $\begin{array}{l}\text { Manufacture of other transport } \\
\text { equipment }\end{array}$ & 0.77 \\
\hline & Manufacture of furniture & 0.74 \\
\hline & Intermediate goods & 0.84 \\
\hline & Investment goods & 0.73 \\
\hline & Consumer non-durables & 0.82 \\
\hline & Other mining and quarrying & 0.76 \\
\hline \multirow{9}{*}{ 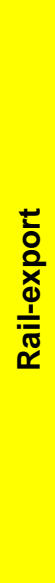 } & Manufacture of food products & 0.70 \\
\hline & $\begin{array}{l}\text { Manufacture of chemicals and } \\
\text { chemical products }\end{array}$ & 0.86 \\
\hline & $\begin{array}{l}\text { Manufacture of rubber and plastic } \\
\text { products }\end{array}$ & 0.84 \\
\hline & Manufacture of basic metals & 0.83 \\
\hline & $\begin{array}{l}\text { Electricity, gas, steam and air } \\
\text { conditioning supply }\end{array}$ & 0.70 \\
\hline & $\begin{array}{l}\text { Electricity, gas, steam and air } \\
\text { conditioning supply }\end{array}$ & 0.70 \\
\hline & Energy goods & 0.73 \\
\hline & Consumer durables & 0.80 \\
\hline & Other mining and quarrying & 0.72 \\
\hline
\end{tabular}

Table 3. Impact assessment for rail- considerable

\begin{tabular}{|c|c|c|}
\hline \multicolumn{3}{|c|}{$\begin{array}{c}\text { Correlation coefficients } \\
0.5<R<0.7-\text { considerable }\end{array}$} \\
\hline $\begin{array}{l}\text { Rail- } \\
\text { import }\end{array}$ & $\begin{array}{l}\text { Repair and installation of } \\
\text { machinery and equipment }\end{array}$ & 0.55 \\
\hline \multirow{6}{*}{$\begin{array}{l}\frac{1}{0} \\
\frac{0}{x} \\
\frac{0}{0} \\
\frac{1}{\bar{J}} \\
\mathbb{\pi}\end{array}$} & $\begin{array}{l}\text { Manufacture of paper and } \\
\text { paper products }\end{array}$ & 0.54 \\
\hline & $\begin{array}{l}\text { Printing and reproduction of } \\
\text { recorded media }\end{array}$ & 0.66 \\
\hline & $\begin{array}{l}\text { Manufacture of other non- } \\
\text { metallic mineral products }\end{array}$ & 0.67 \\
\hline & $\begin{array}{l}\text { Manufacture of electrical } \\
\text { equipment }\end{array}$ & 0.62 \\
\hline & $\begin{array}{l}\text { Manufacture of motor vehicles, } \\
\text { trailers, and semi-trailers }\end{array}$ & 0.54 \\
\hline & $\begin{array}{l}\text { Manufacture of other transport } \\
\text { equipment }\end{array}$ & 0.55 \\
\hline
\end{tabular}

Table 4. Impact assessment for road - high

\begin{tabular}{|c|c|c|}
\hline \multicolumn{3}{|c|}{$\begin{array}{c}\text { Correlation coefficients } \\
0.7<R<0.9-\text { high }\end{array}$} \\
\hline \multirow{5}{*}{ 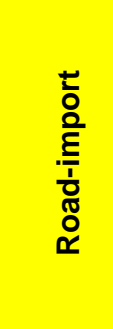 } & Manufacture of beverages & 0.89 \\
\hline & $\begin{array}{l}\text { Manufacture of other non- } \\
\text { metallic mineral products }\end{array}$ & 0.76 \\
\hline & $\begin{array}{l}\text { Manufacture of other transport } \\
\text { equipment }\end{array}$ & 0.90 \\
\hline & Consumer non-durables & 0.78 \\
\hline & Other mining and quarrying & 0.80 \\
\hline $\begin{array}{l}\text { Road- } \\
\text { export }\end{array}$ & $\begin{array}{l}\text { Manufacture of computer, } \\
\text { electronic and optical products }\end{array}$ & 0.83 \\
\hline
\end{tabular}

Table 5. Impact assessment for road - very high

\begin{tabular}{|c|l|c|}
\hline \multicolumn{3}{|c|}{ Correlation coefficients } \\
$0.5<\mathbf{R}<0.7$ - considerable \\
\hline $\begin{array}{l}\text { Road- } \\
\text { import }\end{array}$ & $\begin{array}{l}\text { Manufacture of leather and } \\
\text { related products }\end{array}$ & 0.566 \\
\hline \multirow{2}{*}{$\begin{array}{l}\text { Road- } \\
\text { export }\end{array}$} & $\begin{array}{l}\text { Manufacture of basic } \\
\text { pharmaceutical products and } \\
\text { pharmaceutical preparations }\end{array}$ & 0.613 \\
\cline { 2 - 3 } & Mining of coal and lignite & 0.631 \\
\hline
\end{tabular}

\section{CONCLUSIONS}

- The results indicate six economic activities with very high influence over the railway transport, while no economic activity has such influence over road transport;

- 19 economic activities belong to the high influential group over railway transport, and 6 for the road transport;

- The export by railway transport is influenced by a greater number of economic activities $(20$ 
altogether), compared with the import (11 altogether).

- The economic activities influencing the import by road transport ( 6 altogether) are more than those influencing export ( 3 altogether);

- The import by railway transport is most influenced by manufacturing of other nonmetallic mineral products, while the export by railway transport is most strongly influenced by manufacturing of fabricated metal products, except machinery and equipment;

- The import by road transport is most influenced by manufacturing of beverages, while the export by road transport is most strongly influenced by manufacturing of computer, electronic and optical products.

\section{WORKS CITED}

EC. (2016). Eurostat - Industry, trade, and services. Retrieved from Eurostat: http://ec.europa.eu/eurostat

Jelezov, E., \& Kirilova, G. (2015). Impact of the industry in the Republic of Bulgaria on the transport market demand. 20. Medzinarodna vedecka konferencia Riesenie krizovych situacii $v$ specifickom prostredi. Zilina: Fakulta bezpecnostneho inzinierstva ZU.

NSI. (2016). Short-term Business Statistics. Retrieved from National Statistical Institute: http://www.nsi.bg/en/content/6797/short-term-business-statistics

Received for publication: Revision received:

06.05 .2016

16.09.2016

Accepted for publication:

\section{How to cite this article?}

Style - APA Sixth Edition:

Jelezov, E., \& Kirilova, G. (2017, January 15). Industrial influence on the international freight traffic of the land transports in the Republic of Bulgaria. (Z. Cekerevac, Ed.) MEST Journal, 5(1), 47-56. doi:10.12709/mest.05.05.01.06

Style - Chicago Sixteenth Edition:

Jelezov, Emil, and Gergana Kirilova. "Industrial influence on the international freight traffic of the land transports in the Republic of Bulgaria." Edited by Zoran Cekerevac. MEST Journal (MESTE) 5 , no. 1 (January 2017): 47-56. doi:10.12709/mest.05.05.01.06

Style - GOST Name Sort:

Jelezov Emil and Kirilova Gergana Industrial influence on the international freight traffic of the land transports in the Republic of Bulgaria [Journal] // MEST Journal / ed. Cekerevac Zoran. - Belgrade Toronto : MESTE, January 15, 2017. - 1 : Vol. 5. - pp. 47-56.

Style - Harvard Anglia:

Jelezov, E. \& Kirilova, G., 2017. Industrial influence on the international freight traffic of the land transports in the Republic of Bulgaria. MEST Journal, 15 January, 5(1), pp. 47-56.

Style - ISO 690 Numerical Reference:

Industrial influence on the international freight traffic of the land transports in the Republic of Bulgaria. Jelezov, Emil and Kirilova, Gergana. [ed.] Zoran Cekerevac. 1, Belgrade - Toronto : MESTE, January 15, 2017, MEST Journal, Vol. 5, pp. 47-56. 